American Journal of Environmental Sciences 7 (2): 132-135, 2011

ISSN 1553-345X

(C) 2010 Science Publications

\title{
Effect of $\mathrm{MgCl}_{2}$ on Germination, Growth and Biomass Allocation of the Radish CV. “Cherry Belle”
}

\author{
William Brandenburg and Catherine Kleier \\ Department of Biology, Regis University, 3333 Regis Boulevard, Denver, CO 80221, USA
}

\begin{abstract}
Problem statement: To determine the effect of $\mathrm{MgCl}_{2}$ on radish (Raphanus sativus), plants were grown in controlled environmental growth chambers and given one of three watering treatments; $0.01,0.1$ and $0 \mathrm{M}$ (control) $\mathrm{MgCl}_{2}$. Approach: At high concentrations (0.1 M), $\mathrm{MgCl}_{2}$ was toxic resulting in very low (44\%) germination rates and the subsequent death of all but three undersized plants over the 28 day growth period. Results: At lower concentrations $(0.01 \mathrm{M}), \mathrm{MgCl}_{2}$ resulted in enhanced germination rates (5.55\%) and a mass increase (39.54\%) over the control. Conclusion/Recommendations: While low concentrations of $\mathrm{MgCl}_{2}$ resulted in an increase in total biomass, biomass allocation was shifted largely from roots to shoots (55.88\% higher root/shoot ratio in the control).
\end{abstract}

Key words: Magnesium chloride, environmental growth chambers, biomass allocation, common deicing salt, radish plants, root intensive plant, road deicer, soil toxicity, cherry belle, Analysis Of Variance (ANOVA)

\section{INTRODUCTION}

Millions of tons of salt are applied to road surfaces every winter in the United States and Canada as deicer to allow for safe transit. Roads can receive more than 50 tons of salt per mile annually, with $400-800$ pounds of salt laid per application (Ramakrishna and Viraraghavan, 2005). A large variety of salts, the most prevalent being $\mathrm{NaCl}$, are used as freezing point depressants. $\mathrm{NaCl}$ is effective down to about $-9^{\circ} \mathrm{C}$, so in colder climates other salts must be considered. $\mathrm{MgCl}_{2}$ is a common deicing salt, which is highly effective down to about $-15^{\circ} \mathrm{C}$. Colorado Department of Transportation and other agencies have used $\mathrm{MgCl}_{2}$ and deicers based on $\mathrm{MgCl}_{2}$ in response to lower temperatures (Lewis, 2001; Fischel, 2001).

The large amounts of $\mathrm{MgCl}_{2}$ applied to road surfaces annually is of significant environmental concern as small increases in the concentration of soil and water could have a significant impact on the plants and wild life of affected areas (Dougherty and Smith, 2006). Increased salinity has been reported in ground water 100 $\mathrm{m}$ from roadways and vegetation damage has been reported as far as $200 \mathrm{~m}$ from roads (Ramakrishna and Viraraghavan, 2005). $\mathrm{MgCl}_{2}$ concentrations as low as $0.03 \mathrm{M}$ have been shown to reduce growth in rice and three species of Echinochloa (Kobayashi et al., 2005).
While higher concentrations of $\mathrm{MgCl}_{2}$ may be harmful to plant growth and viability, the magnesium ion is particularly important in higher plant physiology (Shabala and Hariadi, 2005). The negative effects of magnesium deficiency were demonstrated on mulberry plants in an experiment performed by Tewari et al., (2005). The pathological implications of $\mathrm{MgCl}_{2}$ deficiency in plants is of great interest as a growing area of research (Shabala and Hariadi, 2005; Cakmak and Kirkby, 2008).

The magnesium ion, $\mathrm{Mg}^{2+}$ concentration in plant cytosol is the highest of any free divalent cation, typically between $0.002-0.01 \mathrm{M}$ (Shaul, 2002). $\mathrm{Mg}^{2+}$ also plays a very import role in both the light and dark reactions of photosynthesis as the central atom in the chlorophyll molecule and as a metallic cofactor in many enzymes including ATPases, protein kinases and rubisco (Shabala and Hariadi, 2005; Berg et al., 2006). Any plants with insufficient amounts of $\mathrm{Mg}^{2+}$ will likely show a decreased ability to perform photosynthesis and may be susceptible to photooxidative damage (Cakmak and Kirkby, 2008).

The effects of high and low concentrations of $\mathrm{MgCl}_{2}$ on the radish, Raphanus sativus, cv. "Cherry Belle" were tested in this study. As a root intensive plant, the radish may be particularly sensitive to changes in salinity and due to its short life cycle the radish has commonly been used as a bioindicator of soil health (Anjos et al., 2002; Kleier et al., 2001). We

Corresponding Author: W. Brandenburg, Department of Biology, Regis University, 3333 Regis Boulevard, Denver, CO 80221, USA Tel: 314-795-3568 
hypothesized that the $0.1 \mathrm{M} \mathrm{MgCl}_{2}$ water treatment would be lethal to radish and that relatively low concentrations of $\mathrm{MgCl}_{2}(0.01 \mathrm{M})$ would increase germination rates and growth.

\section{MATERIALS AND METHODS}

One hundred eight pots $(453.73 \mathrm{~mL})$ were filled with potting soil (Scotts premium potting) containing $0.07 \%$ nitrogen, $0.01 \%$ phosphate and $0.03 \%$ potash $\left(\mathrm{K}_{2} \mathrm{O}\right)$. Two domestic radish, R. satvius, seeds (Millington Seed Co., Millington, MI) were then planted into each pot. The pots were then set onto 6 trays, each containing 18 pots. Two trays were designated for each treatment and a tray from each treatment was placed into one of two environmental growth chambers. Each growth chamber was given the same settings; $16 \mathrm{~h}$ of sunlight each day at $20^{\circ} \mathrm{C}$ and 8 $\mathrm{h}$ of darkness at $15^{\circ} \mathrm{C}$.

All treatments were watered to capacity so that soil was always moist, approximately $100 \mathrm{ml}$ per pot every 3 days. The control was given tap water and the 0.01- $0.1 \mathrm{M} \mathrm{MgCl}_{2}$ treatments were given tap water containing magnesium chloride hexahydrate (MP biomedicals, Solon, $\mathrm{OH}$ ) at their respective concentrations.

Plant heights were measured on growth day 7, 14 and 21 from the soil to the top of the plant. On growth day 14 , germination rates were recorded and plants were thinned to one per pot. In each case the smallest and/or least healthy looking plants were removed from the pots. One control pot required a transplant as neither seed had germinated.

On the 28 growth day all radish plants were harvested. The plants were carefully pulled from each pot and all soil was removed with water from the roots and shoots. These plants were then dried with a paper towel. Weights of each plant from each treatment were taken and recorded. All plant roots were then cut away from the shoots and the roots and shoots from each treatment were weighed as a group

Plant height and weight differences from each group were compared by Analysis Of Variance (ANOVA) using Systat and germination rates were compared by a Chi-square test using Graphpad.

\section{RESULTS}

The germination rates for each treatment were determined on the growth day 14. The $0.1 \mathrm{M} \mathrm{MgCl}_{2}$ had the lowest germination rate with 32 out of 72 or $44.44 \%$ of seeds germinating Fig. 1. The germination rate for the control was substantially higher with 65 out of 72 or $90.28 \%$ of seeds germinating. The $0.01 \mathrm{M}$ $\mathrm{MgCl}_{2}$ treatment displayed the highest germination rates with 69 out of 72 or $95.83 \%$ of seeds germinating $(X=17.179, \mathrm{p}<0.001)$.

The heights of the plants were recorded on days 7 $(\mathrm{F}=45.020, \mathrm{p}<0.001), 14(\mathrm{~F}=64.080, \mathrm{p}<0.001)$ and 21 (55.345, $\mathrm{p}<0.001$ ). The average plant height for each treatment is displayed in Fig. 2. Both the control and $0.01 \mathrm{M}$ treatment measurements consisted of 36 plants for each measurement day. The number of plants in the $0.1 \mathrm{M}$ treatment varied as on day 7 there were 17 plants, on day 14 there were 21 plants and on day 21 there were 10 plants. While the surving $0.1 \mathrm{M}$ plants are significantly shorter, Fig. 2 does not account for the late sprout and dieing off of plants. Only those plants sprouted and living are accounted for in the diagram.

Chlorosis was seen in both the $0.01 \mathrm{M}$ and control treatments in the last week of the growth period. This effect was substantial for both treatments but more highly pronounced in the $0.01 \mathrm{M}$ plants.

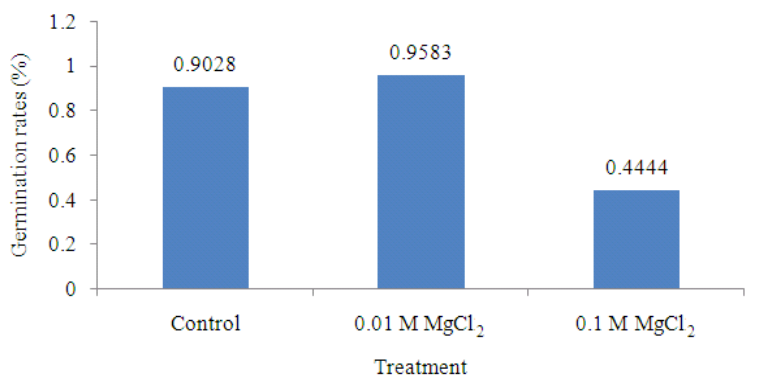

Fig. 1: Germination rates are displayed for each of the three treatments $(\mathrm{p}<0.001)$

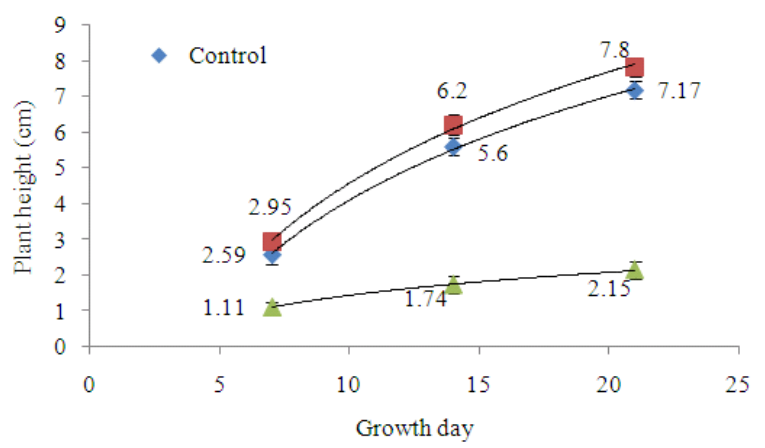

Fig. 2: The average height of plants from each treatment on growth days $7(\mathrm{~F}=45.020$, $\mathrm{p}<0.001), 14(\mathrm{~F}=64.080, \mathrm{p}<0.001)$ and $21(\mathrm{~F}=$ 55.345, $\mathrm{p}<0.001)$. The average height in $\mathrm{cm}$ is recorded next to the points. The control is represented by diamonds, $0.01 \mathrm{M}$ by squares and $0.1 \mathrm{M}$ by triangles 
Am. J. Environ. Sci., 7 (2): 132-135, 2011

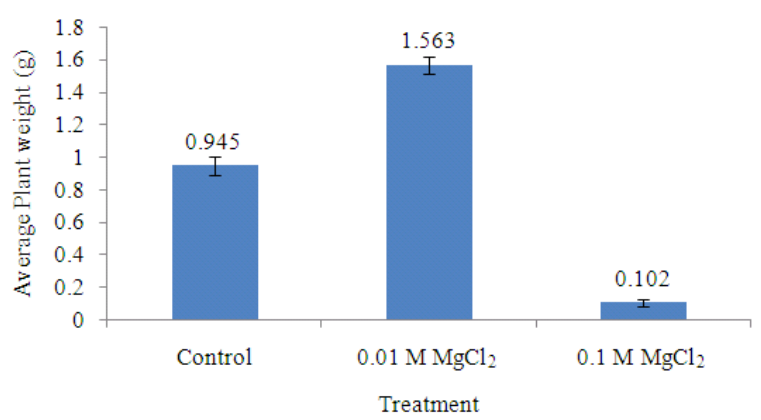

Fig. 3: The average plant weights of each of the three treatments in grams $(\mathrm{F}=56.930, \mathrm{p}<0.001)$

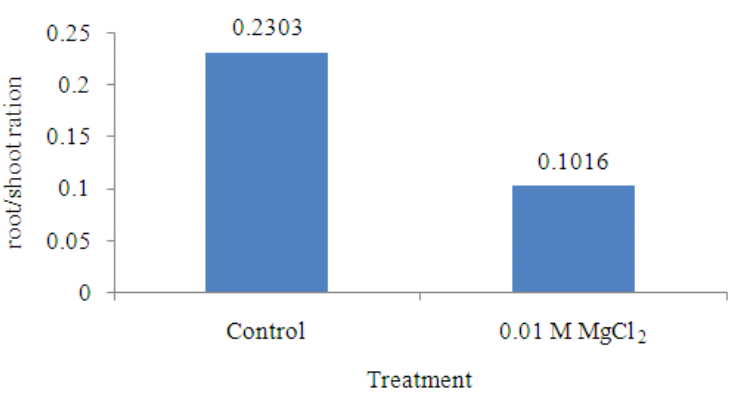

Fig. 4: The average root/shoot ratio of the control and $0.01 \mathrm{M}$ treatments

Table 1: Average plant, root and shoot weights for each of the 3 treatments after harvest

\begin{tabular}{llll}
\hline Treatment & $\begin{array}{l}\text { Plant } \\
\text { weight (g) }\end{array}$ & $\begin{array}{l}\text { Shoot } \\
\text { weight (g) }\end{array}$ & $\begin{array}{l}\text { Root } \\
\text { weight (g) }\end{array}$ \\
\hline Control & 0.945 & 0.765 & 0.176 \\
$0.01 \mathrm{M} \mathrm{MgCl}_{2}$ & 1.563 & 1.412 & 0.144 \\
$0.1 \mathrm{M} \mathrm{MgCl}_{2}$ & 0.102 & 0.085 & 0.014 \\
\hline
\end{tabular}

Plants, roots and shoots were weighed on day 28. The results are displayed in Table 1. By Growth day 28 there were 3 surviving plants in the $0.1 \mathrm{M}$ treatment and 36 plants in the other treatments.

The $0.01 \mathrm{M}$ treatment had plants with greatest average biomass, approximately $39.54 \%$ more biomass than the control. The three surviving plants from the 0.1 $\mathrm{M}$ treatment were by far the smallest with an average biomass $81.38 \%$ lower than the control $(F=56.930$, $p$ $<0.001$ ). The average plant weights of the 3 treatments are displayed in Fig. 3.

The root,shoot ratio for the control and $0.01 \mathrm{M}$ treatments is displayed in Fig. 4. The data from the 0.1 $\mathrm{M}$ plants is not included in the root,shoot ratio discussion because of the small sample size and small plants. The $0.01 \mathrm{M}$ treatment allocated significantly more mass to its shoot than the control. The root/shoot ratio of the control was 0.2303 , more than double the $0.1016 \mathrm{root} / \mathrm{shoot}$ ratio of the $0.01 \mathrm{M}$ treatment.

\section{DISCUSSION}

High concentrations of $\mathrm{MgCl}_{2}(0.1 \mathrm{M})$ significantly reduced the germination rate, height and weight of radish. Of the 32 plants that had germinated by day 14, only 3 survived to harvest on day 28 . This demonstrates the toxicity of $\mathrm{MgCl}_{2}$ at high concentrations to radish. A possible explanation for the dieing off of plants in the $0.1 \mathrm{M}$ treatment could be the build of $\mathrm{MgCl}_{2}$ in the soil. Each time plants received water some $\mathrm{MgCl}_{2}$ may have been absorbed into the soil thereby increasing soil toxicity. This phenomenon could also provide an explanation for the onset of chlorosis in the $0.01 \mathrm{M}$ $\mathrm{MgCl}_{2}$ treatment in the final week of the growth cycle. The negative effects of high $\mathrm{MgCl}_{2}$ concentrations have also been demonstrated on other plant species (Kobayashi et al., 2005).

The $0.01 \mathrm{M} \mathrm{MgCl}_{2}$ treatment showed increased germination rates, height and weight over the control. This indicates that moderate concentrations of $\mathrm{MgCl}_{2}$ may be beneficial to radish. This is likely due to the importance of the $\mathrm{Mg}^{2+}$ cation in plant physiology (Shabala and Hariadi, 2005).

The smaller root to shoot ratio in the $0.01 \mathrm{M}$ treatment may have occurred due to access $\mathrm{MgCl}_{2}$ concentrations in the soil. Plants take up $\mathrm{Mg}^{2+}$ from the soil through their roots (Shaul, 2002). Increased $\mathrm{Mg}^{2+}$ availability may have decreased the need for root surface area in the $0.01 \mathrm{M}$ treatment. Decreased $\mathrm{Mg}^{2+}$ availability in the control may have increased the root/shoot ratio, providing more surface area at the root/soil junction, allowing for better $\mathrm{Mg}^{2+}$ absorption from the soil. Individual plant roots and shoots were not weighed, which greatly limited statistical power. The fact that some plants had bolted and some had not may have skewed the root/shoot ratio findings. More tests are needed to confirm this result.

While it is known that $\mathrm{Mg}^{2+}$ is an important metal in plant biology, relatively few studies on the effects of $\mathrm{MgCl}_{2}$ on plant growth have been published. Particularly studies identifying the toxicity of the salt at higher concentrations. The large amount of $\mathrm{MgCl}_{2}$ used annually as road deicer merits a need for more research.

More experiments are needed to validate the findings in this experiment. Varying the $\mathrm{MgCl}_{2}$ water concentration on radish and other plant species may be beneficial in determining lethal, harmful and beneficial concentrations. To complement these experiments, the amount of $\mathrm{MgCl}_{2}$ absorbed and retained in the soil used to grow the plants must also be determined. This could then be compared to the amount of $\mathrm{MgCl}_{2}$ found in soils surrounding roads receiving deicing treatments. The final goal being a semi-quantitative understanding 
of the amount of salt which can be applied annually to roads, while keeping $\mathrm{MgCl}_{2}$ soil concentrations below the experimentally determined harmful value.

\section{CONCLUSION}

Radish is sensitive to different concentrations of $\mathrm{MgCl}_{2}$ in soil and water. While lower concentrations $(0.01 \mathrm{M})$ can positively effect growth and development, higher concentrations $(0.1 \mathrm{M})$ can be lethal.

\section{ACKNOWLEDGEMENT}

The researchers would like to thank Chris Cooley for his assistance in acquiring and maintaining lab materials as well as Alex Potts and Josh Wagner for watering plants.

\section{REFERENCES}

Anjos, M.J., R.T. Lopes, E.F.O. Jesus, J.T. Assis and R. Cesario et al., 2002. Elemental concentration analysis in soil contaminated with recyclable urban garbage by tube-excited energy-dispersive X-ray fluorescence. Radiation Phys. Chem., 65: 495-500. DOI: 10.1016/S0969-806X(02)00356-0

Berg, J.M., J.L. Tymoczko and L. Stryer, 2006. Biochemistry Lecture Notebook. 6th Edn., W.H. Freeman and Co, New York, ISBN-10: 0716771578, pp: 600.

Cakmak, I. and E.A. Kirkby, 2008. Role of magnesium in carbon partitioning and alleviating photooxidative damage. Physiol. Plantarum, 133: 692-704. DOI: 10.1111/J.1399-3054.2007.01042.X

Dougherty, C.K. and G.R. Smith, 2006. Acute effects of road de-icers on the tadpoles of three anurans. Applied Herpetol., 3: 87-93. DOI: 10.1163/157075406776984266
Fischel, M., 2001. Evaluation of selected deicers based on a review of the literature. Colorado department of transportation. http://sbisrvntweb.uqac.ca/archivage/17775044.pdf

Kleier, C., B. Farnsworth and W. Winner, 2001. Photosynthesis and biomass allocation of radish cv. "Cherry Belle" in response to root temperature and ozone. Environ. Pollut., 111: 127-133. DOI: 10.1016/S0269-7491(99)00326-7

Kobayashi, H., Y. Masaoka and S. Sato, 2005. Effects of excess magnesium on the growth and mineral content of rice and Echinochloa. Plant Prod. Sci., 8: 38-43. DOI: 10.1626/PPS.8.38

Lewis, W.M., 2001. Evaluation and Comparison of Three Chemical Deicers for use in Colorado. Colorado department of transportation. http://www.coloradodot.info/programs/research/pd fs/2001/3chemicaldeicers.pdf

Ramakrishna, D.M. and T. Viraraghavan, 2005. Environmental impact of chemical deicers-a review. Water, Air, Soil Pollut., 166: 49-63. DOI: 10.1007/s11270-005-8265-9

Rout, G.R. and P. Das, 2002. Effect of metal toxicity on plant growth and metabolism: I. Zinc. Agron. Sustain. Dev., 23: 3-11. DOI: 10.1051/agro:2002073

Shabala, S. and Y. Hariadi, 2005. Effects of magnesium availability on the activity of plasma membrane ion transporters and light-induced responses from broad bean leaf mesophyll. Planta, 221: 56-65. PMID: 15645306

Shaul, O., 2002. Magnesium transport and function in plants: The tip of the iceberg. Biometals, 15: 307-321. DOI: $10.1023 / \mathrm{A}: 1016091118585$

Tewari, R.K., P. Kumar and P.N. Sharma, 2005. Magnesium deficiency induced oxidative stress and antioxidant responses in mulberry plants. Sci. Hortic., 108: 7-14. DOI: 10.1016/J.SCIENTA.2005.12.006 